\title{
Pelatihan Pengembangan Instrumen Evaluasi Online Menggunakan Google ForM BAGI GURU SEKOLAH DASAR/MADRASAH IBTIDAIYAH
}

\author{
${ }^{1}$ Harina Fitriyani, ${ }^{2}$ Dwi Astuti \\ ${ }^{1,2}$ Universitas Ahmad Dahlan, Yogyakarta \\ email: ' harina.fitriyani@pmat.uad.ac.id;2dwi.astuti@pmat.uad.ac.id
}

\begin{abstract}
The Covid-19 pandemic forces all elements of society to adapt to new activities that were not usually done before, including online learning. To carry out learning evaluations during online learning, some teachers still have not optimized the use of available Platforms, such as the free Platform like Google Form. Therefore, it is necessary to have community service activities in the form of training on the development of online evaluation instruments for teachers. The purpose of the training is to improve the professionalism of teachers in the use of the Google Form application with the ExtendedForms add-on. The training was carried out virtually through the Zoom Meeting and was attended by fifth-grade teachers of Elementary School/Madrasah Ibtidaiyah Muhammadiyah throughout Bantul Regency. The training activity methods include lectures, practice, and questions and answers. This training results were participants who participated in as many as 38 teachers, a speaker delivered material about online evaluation in online learning, introduction to the Google Form Platform followed by practice compiling quiz questions using Google Form. After participating in this training, participants have understood what facilities can be optimized when developing online evaluation instruments using the Google Form Platform, such as the shuffle option order, shuffle question order, and limit timer feature with the Extended Forms add-on. After attending the training, there is an increase in the teacher's ability to maximize the Google Form application with the ExtendedForms add-on.
\end{abstract}

Keywords: Online Evaluation, Google Form, Online Learning

\begin{abstract}
Abstrak. Adanya pandemi Covid-19 memaksa semua elemen masyarakat untuk beradaptasi dengan kegiatan baru yang tidak biasa dilakukan sebelumnya, diantaranya adalah pembelajaran daring. Untuk melaksanakan evaluasi pembelajaran selama pembelajaran daring, beberapa guru masih belum mengoptimalkan penggunaan Platform yang tersedia, seperti Platform tak berbayar Google Form. Oleh karena itu perlu adanya kegiatan pengabdian kepada masyarakat berupa pelatihan pengembangan instrumen evaluasi online bagi guru. Adapun tujuan pelatihan adalah untuk meningkatkan profesionalisme guru dalam penggunaan aplikasi Google Form dengan add-on ExtendedForms. Pelatihan dilaksanakan secara virtual melalui Zoom Meeting dan diikuti oleh 38 guru kelas $V$ Sekolah Dasar/Madrasah Ibtidaiyah Muhammadiyah se-Kabupaten Bantul. Adapun metode kegiatan pelatihan berupa ceramah, praktek, dan tanya jawab. Hasil kegiatan pelatihan ini yaitu peserta telah memahami fasilitas-fasilitas apa saja yang bisa dioptimalkan ketika mengembangkan instrumen evaluasi online menggunakan Platform Google Form seperti fitur shuffle option order, shuffle question order, dan limit timer dengan add-on ExtendedForms. Selain itu juga peserta telah mendapatkan pengalaman langsung menggunakan Google Form. Setelah mengikuti pelatihan, terdapat peningkatan kemampuan guru dalam memaksimalkan aplikasi Google Form dengan add-on ExtendedForms.
\end{abstract}

Kata Kunci: Evaluasi Online, Google Form, Pembelajaran Daring. 


\section{Pendahuluan}

Sejak akhir tahun 2019, dunia dihebohkan dengan kemunculan Corona Virus Desease 19 (Covid-19) yang pertama kali terdeteksi di Negara China. Virus tersebut menyebar secara masif ke berbagai Negara termasuk Indonesia sehingga menyebabkan adanya pandemi berkepanjangan. Berbagai upaya telah dilakukan untuk menekan angka kasus positif Covid-19 diantaranya dengan physical distancing maupun social distancing. Pandemi Covid-19 telah menyebabkan beberapa sektor strategis mengalami masalah, termasuk pendidikan. Banyak Negara terdampak Covid-19 telah memberlakukan penutupan sekolah atau menerapkan pembelajaran online melalui belajar dari rumah sebagai upaya physical distancing untuk mencegah penularan Covid-19 (Basilaia \& Kvavadze, 2020; Favale et al., 2020; Radwan \& Radwan, 2020; Sintema, 2020; Viner et al., 2020; Zayapragassarazan, 2020; Zhang et al., 2020).

Badan Pemerintah Indonesia melalui Bencana (BNPB) menetapkan masa tanggap darurat Covid-19 sejak tanggal 29 Februari 2020. Menindaklanjuti surat edaran BNPB tersebut, Menteri Pendidikan dan Kebudayaan mengeluarkan edaran yang berisi anjuran pembelajaran dari rumah (BDR) melalui pembelajaran dalam jaringan (daring). Selama pelaksanaan pembelajaran daring, Mendikbud menekankan BDR dilaksanakan untuk memberikan pengalaman belajar yang bermakna bagi peserta didik (Kemendikbud, 2020). Tidak hanya penyampaian materi saja yang dilakukan secara daring, evaluasi pembelajaran pun juga dilakukan secara daring.
Mata pelajaran matematika bagi sebagian peserta didik SD kelas V masih dianggap sebagai pelajaran yang sulit (Siregar \& Restati, 2017). Pembelajaran dilakukan secara tatap muka langsung, dimana peserta didik dapat langsung berinteraksi dengan guru apabila belum paham dengan materi yang dipelajari saja terkadang masih dirasa sulit. Apalagi, pada situasi pandemi Covid-19 saat ini, dimana pembelajaran dilakukan secara daring, kesulitan itu kemungkinan masih dirasakan peserta didik karena peserta didik dituntut untuk belajar mandiri, selain mendapat penjelasan materi maupun instruksi kerja dari guru via daring. Peserta didik kurang leluasa bertanya kepada guru maupun temannya secara langsung. Oleh karena itu, diperlukan evaluasi kegiatan pembelajaran matematika untuk mengetahui sejauh mana materi yang disampaikan guru telah dipahami peserta didik dengan baik. Sehingga, guru memiliki gambaran untuk perbaikan pembelajaran selanjutnya.

Banyak Platform yang bisa digunakan untuk mendukung proses pembelajaran daring. Salah satu Platform yang cukup banyak dikenal oleh guru dan peserta didik adalah Platform yang diluncurkan oleh Google yaitu Google Classroom, Google Meeting, maupun Google Formulir atau biasa disebut Google Form. Semua aplikasi tersebut tidak berbayar. Google Form merupakan salah satu aplikasi pembuat kuis online dan survey online yang bisa digunakan untuk mendukung pelaksanaan evaluasi pembelajaran daring. Baik evaluasi pembelajaran dengan bentuk soal pilihan ganda maupun soal uraian. Beberapa fungsi Google Form dalam dunia pendidikan adalah: 1) memberikan tugas latihan/ulangan online melalui laman website, 2) mengumpulkan pendapat orang lain melalui laman website, 3) 
mengumpulkan berbagai data peserta didik atau guru melalui laman website, 4) membuat formulir pendaftaran online untuk sekolah, dan 5) membagikan kuesioner kepada orang secara online (Batubara, 2016).

Sejauh ini, penggunaan Google Form untuk evaluasi pembelajaran belum banyak mengoptimalkan menumenu yang ada seperti fasilitas kuis sehingga guru bisa memberi skor jawaban benar, acak pilihan jawaban, acak urutan soal, limit timer, kolaborator dll. Untuk menambahkan limit timer, guru bisa mengintegrasikan Google Form dengan aplikasi lain dengan cara melakukan add-on ExtendedForms yang bisa diinstal secara gratis dari layanan Google. Agar dapat membuat kuis atau survey online menggunakan aplikasi Google Form maka pertama kali yang harus dilakukan adalah membuat akun di Google.

Hasil survey pendahuluan terhadap guru SD/MI Muhammadiyah di Kabupaten Bantul diperoleh data bahwa $37,5 \%$ guru telah menggunakan Platform Google Form untuk evaluasi pembelajaran dan sisanya melakukan evaluasi pembelajaran dengan memberikan soal-soal yang tidak memberatkan melalui media cetak yang diambil wali murid ke sekolah (12,5\%), langsung memberi pertanyaan pada saat pertemuan virtual di Google Meeting (25\%), Semi daring (12,5\%), dan peserta didik datang ke sekolah langsung bertemu guru (12,5\%). Selain untuk evaluasi pembelajaran, sebanyak $12,5 \%$ guru ternyata menggunakan Google Form untuk proses pembelajaran daring di masa pandemi ini.

Adanya pandemi memaksa semua elemen masyarakat untuk beradaptasi dengan kegiatan baru yang belum atau jarang dilakukan sebelumnya. Dalam pembelajaran, guru dan peserta didik dituntut untuk mampu menyesuaikan keadaan dan mahir menggunakan teknologi agar kegiatan pembelajaran tetap berjalan meski dengan situasi yang baru. Kekurangsiapan guru, peserta didik, infrastruktur, serta fasilitas yang ada telah menimbulkan adanya kendala dalam pembelajaran daring. Berdasarkan hasil survey pendahuluan, beberapa kendala yang dihadapi guru SD/MI Muhammadiyah di Bantul dalam melakukan evaluasi pembelajaran antara lain guru tidak bisa mengidentifikasi kemampuan peserta didik $(10 \%)$, orang tua bekerja seharian sehingga tidak optimal mendampingi peserta didik belajar $(10 \%)$, peserta didik slow-learner mengalami kesulitan mengikuti pembelajaran $(10 \%)$, peserta didik tergantung pada orang tua selama BDR (10\%), peserta didik kurang paham materi yang disampaikan guru (30\%), kendala jaringan $(10 \%)$, peserta didik malas mengerjakan/merespon soal tanpa pendampingan guru $(10 \%)$, dan peserta didik tidak aktif (10\%).

Penggunaan Platform Google

Form dalam pelaksanaan evaluasi pembelajaran telah banyak dilakukan, seperti Astuti (2018) menggunakan Google Form untuk Self Assesment; Yusron (2020) melakukan PKM bagi guru-guru SD berupa pelatihan membuat kuis online menggunakan Google Form yang berfokus pada edit nilai kuis, menambah gambar pada kuis, dan mengunggah kuis ke halaman blog atau web; Krisnawati (2018) memanfaatkan Google Form sebagai kuis online mata kuliah Trigonometri; Ritonga dkk. (2020) melakukan PKM bagi guru Pendidikan Agama Islam (PAI) dalam bentuk sosialisasi penggunaan Google Form dalam melaksanakan evaluasi pembelajaran; dan Bahri dkk. (2020) melakukan pelatihan pemanfaatan Google Form bagi guru SMK di Sota dan diperoleh temuan bahwa kompetensi guru di 
bidang TIK masih kurang. Dalam kegiatan PKM yang kami lakukan, penggunaan Google Form untuk pelaksanaan evaluasi pembelajaran difokuskan terhadap optimalisasi fasilitas Google Form berupa acak urutan soal, acak pilihan jawaban, serta pengaturan limit timer pada soal kuis online untuk melatih karakter peserta didik berkaitan dengan sikap jujur, mandiri, tanggung jawab, kerja keras dan disiplin.

Untuk dapat melakukan pembelajaran daring, keahlian dan keterampilan diperlukan oleh setiap guru untuk memanfaatkan teknologi informasi dalam melaksanakan pembelajaran daring (Djusar et al., 2020). Berdasarkan paparan di atas, maka perlu adanya kegiatan pengabdian kepada masyarakat (PKM) sebagai sumbangsih dosen di Perguruan Tinggi dalam upaya pemerintah menjaga keberlangsungan pembelajaran di masa pandemi Covid-19. Oleh karena itu, kami melaksanakan kegiatan PKM dengan judul "Pelatihan Pengembangan Instrumen Evaluasi Online pada guru Sekolah Dasar/Madrasah Ibtidaiyah". Secara umum kegiatan PKM yang dilakukan bertujuan untuk meningkatkan profesionalisme guru SD/MI Muhammadiyah di Kabupaten Bantul terutama dalam melaksanakan pembelajaran daring di masa pandemi ini. Adapun secara khusus, pelatihan yang dilakukan bertujuan untuk meningkatkan profesionalisme guru dalam penggunaan aplikasi Google Form dengan add-on ExtendedForm.

\section{Metode Ilmiah}

Untuk mencapai tujuan kegiatan yang telah dipaparkan di atas, maka metode PKM yang dipilih adalah pelatihan dan pendampingan. Mengingat masih dalam situasi pandemi Covid-19 dimana pembelajaran dilaksanakan secara daring, maka kegiatan PKM ini bertempat di kediaman masing-masing peserta, baik di rumah atau di kantor, melalui ruang virtual mode sinkron dengan Platform Zoom Meeting dan mode asinkron dengan menggunakan Platform Google Classroom. Kegiatan PKM ini diikuti oleh 38 orang guru matematika kelas $\mathrm{V}$ SD/MI Muhammadiyah se-Kabupaten Bantul. Waktu pelaksanaan pelatihan dan pendampingan ini pada tanggal 18 28 November 2020. Kegiatan pelatihan secara resmi dibuka pada hari Rabu, 18 November 2020 oleh Kaprodi Pendidikan Matematika FKIP UAD dan Sekretaris Majelis Pendidikan Dasar dan Menengah Pimpinan Daerah Muhammadiyah (Dikdasmen PDM) Bantul. Adapun teknis pelaksanaan pelatihan dilakukan dengan metode ceramah, praktik, dan diakhiri dengan sesi tanya jawab. Tabel 1 berikut menyajikan garis besar program kegiatan yang dilakukan.

Tabel 1.

\begin{tabular}{|c|c|c|}
\hline \multicolumn{3}{|c|}{ Program kegiatan } \\
\hline Program & $\begin{array}{c}\text { Indikator } \\
\text { keberhasilan } \\
\text { yang dicapai }\end{array}$ & $\begin{array}{c}\text { Catatan } \\
\text { perkembanga } \\
\text { n kegiatan }\end{array}$ \\
\hline $\begin{array}{l}\text { Pemaparan } \\
\text { Materi tentang } \\
\text { evaluasi } \\
\text { pembelajaran } \\
\text { matematika } \\
\text { online }\end{array}$ & $\begin{array}{l}\text { Peserta } \\
\text { menguasai } \\
\text { evaluasi } \\
\text { pembelajaran } \\
\text { matematika } \\
\text { online }\end{array}$ & \begin{tabular}{ll}
\multicolumn{2}{l}{ Narasumber } \\
memaparkan \\
materi via \\
Zoom dan \\
diskusi \\
singkat \\
dengan \\
peserta
\end{tabular} \\
\hline $\begin{array}{l}\text { Pemaparan } \\
\text { materi } \\
\text { sosialisasi } \\
\text { penggunaan } \\
\text { Google Form }\end{array}$ & $\begin{array}{l}\text { Peserta } \\
\text { memahami } \\
\text { fasilitas-fasilitas } \\
\text { yang dapat } \\
\text { dioptimalkan } \\
\text { menggunakan } \\
\text { Platform } \\
\text { Google Form }\end{array}$ & $\begin{array}{l}\text { Narasumber } \\
\text { memaparkan } \\
\text { materi } \\
\text { kemudian } \\
\text { dilanjutkan } \\
\text { dengan } \\
\text { diskusi } \\
\text { singkat } \\
\text { dengan } \\
\text { peserta }\end{array}$ \\
\hline $\begin{array}{l}\text { Praktek } \\
\text { membuat soal } \\
\text { dengan } \\
\text { Google Form }\end{array}$ & $\begin{array}{l}\text { Peserta mampu } \\
\text { membuat soal } \\
\text { dengan Google } \\
\text { Form }\end{array}$ & $\begin{array}{l}\text { Peserta } \\
\text { berperan } \\
\text { sebagai guru } \\
\text { untuk } \\
\text { membuat soal } \\
\text { dengan } \\
\text { Google Form, } \\
\text { dan sebagai } \\
\text { murid untuk } \\
\text { mengerjakan }\end{array}$ \\
\hline
\end{tabular}




\begin{tabular}{|c|c|c|}
\hline Program & $\begin{array}{c}\text { Indikator } \\
\text { keberhasilan } \\
\text { yang dicapai }\end{array}$ & $\begin{array}{c}\text { Catatan } \\
\text { perkembanga } \\
\text { n kegiatan }\end{array}$ \\
\hline & & $\begin{array}{l}\text { soal di } \\
\text { Google Form. }\end{array}$ \\
\hline $\begin{array}{l}\text { Pendampinga } \\
\mathrm{n} \text { pembuatan } \\
\text { soal dengan } \\
\text { Google Form }\end{array}$ & $\begin{array}{l}\text { Peserta mampu } \\
\text { mengaplikasika } \\
\mathrm{n} \text { materi } \\
\text { pelatihan dalam } \\
\text { menyusun } \\
\text { instrument } \\
\text { evaluasi } \\
\text { matematika } \\
\text { daring }\end{array}$ & $\begin{array}{l}\text { Pendampinga } \\
\mathrm{n} \text { dilakukan } \\
\text { dalam } \\
\text { platform } \\
\text { Google } \\
\text { Classroom } \\
\text { dengan durasi } \\
1 \quad \text { pekan } \\
\text { setelah } \\
\text { pelatihan } \\
\text { virtual }\end{array}$ \\
\hline
\end{tabular}

Untuk mengukur peningkatan, pemahaman, dan penguasaan peserta tentang materi pelatihan maka diberikan angket sebelum dan setelah pelatihan. Angket terdiri dari 6 pertanyaan tentang kemampuan peserta mengoptimalkan platform Google Form yang meliputi kemampuan membuat kuis (KMK), pengaturan setting timer (PST), pengaturan pengacak soal (PPS), pembuatan pengacak pilihan jawaban (PPPJ), pembuatan kunci jawaban kuis (PKJK), dan penggunaan fasilitas pemberian nilai kuis (PFPNK). Adapun pilihan jawaban menggunakan skala 5 dari rentang skor 1 (Tidak Menguasai) hingga skor 5 (Sangat Menguasai).

Selama kegiatan PKM ini penulis melibatkan 3 orang mahasiswa program studi Pendidikan matematika FKIP UAD. Keterlibatan mahasiswa dalam kegiatan itu sebagai tenaga teknis selama pelatihan virtual di ruang Zoom Meeting. Tugas ketiga mahasiswa diantaranya, yaitu pertama menjadi cohost Zoom Meeting yang bertugas mengadmit peserta yang join Zoom Meeting. Kedua, menjadi master of ceremony (MC) selama pelatihan. Ketiga, bertugas sebagai pembaca Ayat Suci Alquran pada sesi pembukaan. Keempat, merekap kehadiran peserta pelatihan. Terakhir, menjadi tenaga teknis operator materi yang ditayangkan pada ruang virtual Zoom Meeting

\section{Hasil dan Pembahasan}

Sebelum pelatihan dimulai, peserta diminta mengisi kuesioner untuk mengetahui pemahaman peserta tentang materi yang akan disampaikan. Berdasarkan hasil pelatihan diperoleh bahwa pemahaman dan penguasaan peserta tentang platform Google Form sebelum pelatihan menunjukkan bahwa $74,4 \%$ peserta pernah menggunakan Google Form dalam pembelajaran, $53,8 \%$ peserta belum pernah menggunakan aplikasi limit timer dalam membuat soal/kuis, $64,1 \%$ peserta belum pernah menggunakan fasilitas acak urutan soal, dan $66,7 \%$ peserta belum pernah menggunakan fasilitas acak pilihan jawaban pada Platform Google Form.

Sesi pertama pelatihan yaitu pemaparan materi tentang evaluasi pembelajaran online. Materi yang disampaikan pada sesi pertama ini antara lain kebijakan pemerintah tentang pembelajaran daring, ketentuan pembelajaran dari rumah, prinsip evaluasi di masa pandemi Covid-19, dan pengenalan beberapa Platform yang bisa dimanfaatkan untuk melakukan evaluasi pembelajaran daring.

Berdasarkan Surat Edaran Mendikbud No. 4 tahun 2020 menjelaskan bahwa beberapa ketentuan yang dapat dijadikan panduan dalam melaksanakan pembelajaran secara daring yaitu pembelajaran ditekankan pada pemberian pengalaman bagi peserta didik, tidak terbebani tuntutan menuntaskan seluruh capaian kurikulum untuk kenaikan kelas atau kelulusan, dan perlu mempertimbangkan pemberian tugas agar tidak terlalu membebani bagi peserta didik atau orang tua.

Evaluasi pembelajaran yang dilaksanakan secara daring seharusnya juga memperhatikan proses pembelajaran yang dilaksanakan. Evaluasi dapat dilaksanakan secara 
fleksibel dalam konteks teknis pelaksanaannya. Evaluasi pembelajaran yang dilakukan harus disesuaikan dengan fasilitas yang dimiliki oleh peserta didik. Selain itu, evaluasi yang diberikan kepada peserta didik seharusnya diberi feedback. Feedback ini sangatlah penting bagi peserta didik. Feedback dapat dijadikan sebagai bahan perbaikan bagi peserta didik. Jika guru tidak memberikan feedback, maka peserta didik tidak akan mengetahui sejauh mana pemahaman peserta didik terhadap materi yang sudah dipelajari. Ketentuan lain dalam melaksanakan evaluasi yaitu berkaitan dengan instrumen yang digunakan. Instrumen evaluasi yang digunakan harus memenuhi kriteria valid dan reliabel.

Dalam paparan materi juga, disampaikan beberapa tools yang dapat digunakan untuk melakukan evaluasi pembelajaran. Hal yang ditekankan adalah tidak ada tool terbaik untuk melakukan evaluasi secara daring. Tool yang baik untuk melakukan evaluasi pembelajaran adalah yang sesuai dengan karakteristik peserta didik, karakteristik materi, dan fasilitas yang dimiliki oleh peserta didik. Dokumentasi kegiatan pelatihan sesi satu secara virtual melalui Zoom Meeting dapat dilihat pada Gambar 1 berikut.

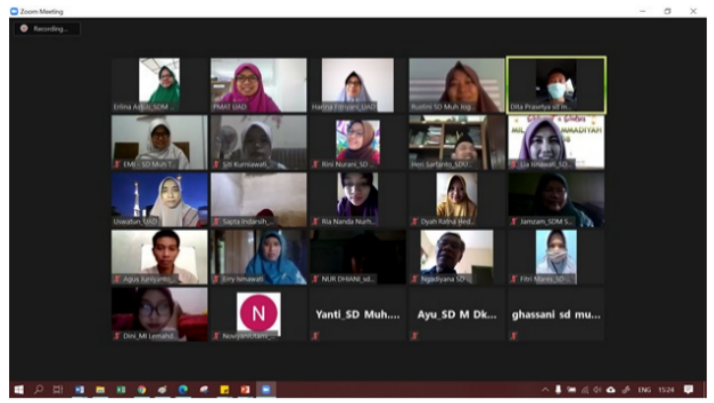

Gambar 1. Pelatihan Virtual via Zoom Meeting

Pada sesi kedua pelatihan, yaitu pemaparan sekaligus praktik pembuatan soal kuis menggunakan Platform Google Form. Adapun materi yang disampaikan oleh narasumber pada sesi kedua meliputi pengenalan Platform Google Form, sosialisasi fasilitas yang ada pada Google Form meliputi membuat kuis online dilengkapi dengan pemberian skor dan pemberian respon atas jawaban peserta didik, fasilitas acak urutan soal (shuffle question order) dan acak pilihan jawaban (shuffle option order), limit timer dengan mengintegrasikan Google Form dan aplikasi lain dengan cara melakukan add-on dengan aplikasi ExtendedForms. Selama pembelajaran daring, guru tentu tidak leluasa mengawasi peserta didiknya terutama ketika peserta didik mengikuti evaluasi pembelajaran. Misalkan peserta didik melakukan kecurangan selama mengerjakan soal yang diberikan guru, tentu guru tidak akan tahu hal itu. Hal ini telah menjadi kekhawatiran beberapa guru dan bahkan dosen dalam forum-forum Webinar yang banyak dilaksanakan selama masa pandemi, yaitu pembentukan karakter peserta didik selama mengikuti pembelajaran daring. Untuk meminimalisir terbentuknya karakter negatif peserta didik selama pembelajaran daring terutama dalam pelaksanaan evaluasi pembelajaran, maka guru perlu melakukan inovasi dan kreativitas dalam pembelajarannya. Salah satunya adalah dengan mengembangkan soal online yang memungkinkan peserta didik tidak bisa melakukan kecurangan meski tanpa pengawasan langsung dari guru. Dengan menggunakan fasilitas acak urutan soal (Shuffle question order) pada setelan (setting-Presentation), setiap peserta didik akan melihat soal pada layarnya dengan urutan yang berbeda. Sedangkan dengan fasilitas acak pilihan jawaban (Shuffle option order) di bagian pojok kanan bawah pada setiap slide soal kuis. Setiap peserta didik akan melihat soal pada layarnya dengan urutan pilihan jawaban 
yang tidak sama untuk soal yang sama dengan peserta didik lainnya. Bila kedua fasilitas Google Form dioptimalkan guru dalam membuat soal atau kuis online maka dimungkinkan peserta didik tidak bisa menyontek maupun memberi sontekan ke peserta didik lain. Selain itu, dengan menambahkan fitur add-on

ExtendedForms, guru dapat mengatur durasi pengerjaan soal atau kuis online dan mengatur berapa kali satu akun bisa mengerjakan kuis online yang diberikan. Penggunaan add-on ExtendedForms mengharuskan peserta didik untuk mendaftar via email, kemudian akan mendapatkan link soal/kuis online melalui email terdaftar. Dengan fitur ini, ketika peserta didik belum selesai mengerjakan namun waktu yang diberikan sudah berakhir maka secara otomatis sistem akan menyimpan jawaban peserta didik. Adapun karakter positif peserta didik yang bisa dibentuk melalui optimalisasi Google Form antara lain karakter jujur, disiplin, kerja keras, tanggung jawab, dan mandiri. Dengan demikian, pembentukan karakter positif peserta didik tetap bisa dilakukan meskipun evaluasi dilakukan secara jarak jauh atau online.

Kegiatan pelatihan diakhiri dengan sesi tanya jawab. Diantara pertanyaan yang diajukan oleh peserta terkait pemberian skor pada soal kuis online. Pemberian skor tiap soal pada kuis online dengan Google Form dilakukan manual per soal, sehingga guru bisa mengatur skor tiap-tiap soal jika akan dibedakan skornya, termasuk memberi skor nol pada identitas peserta didik. Setelah sesi tanya jawab, peserta diminta memberikan kesan-kesan mengikuti pelatihan. Diantara kesan yang disampaikan oleh peserta adalah materi pelatihan yang diberikan menarik, menambah ilmu dan pengalaman baru dalam menyusun instrumen evaluasi nantinya terutama bagi guru yang belum pernah menggunakan Platform Google Form dalam proses evaluasi pembelajarannya. Dari kegiatan pelatihan menunjukkan ada peningkatan kemampuan guru menggunakan platform Google Form dalam pembelajaran khususnya evaluasi pembelajaran selama masa pandemi. Sebagaimana disajikan pada Gambar 2 berikut.

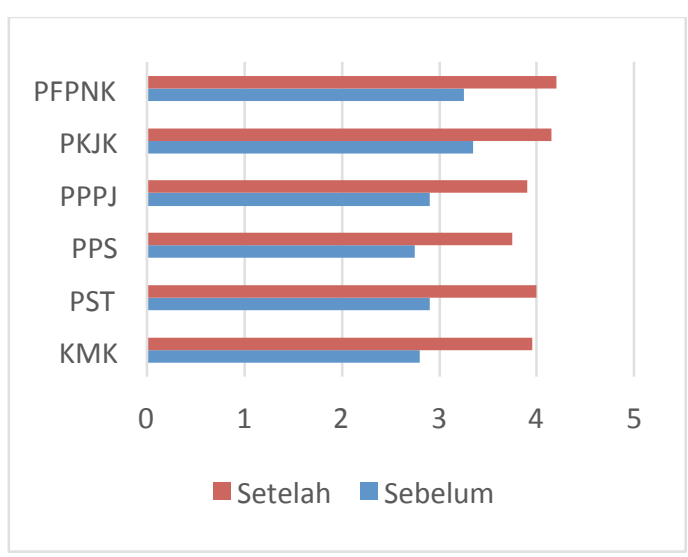

Gambar 2. Peningkatan Penguasaan Google Form Peserta

Berdasarkan Gambar 2 menunjukkan bahwa penguasaan guru tentang fasilitas yang disediakan pada Google Form mengalami peningkatan terbesar pada kemampuan membuat kuis online. Sebelum pelatihan rata-rata sebesar 2,8 meningkat menjadi 3,95 (meningkat 1,15). Peningkatan terbesar kedua yakni pada aspek pengaturan setting timer meningkat sebesar 1,1 dari rata-rata sebelum pelatihan 2,9. Sedangkan kemampuan guru dalam menggunakan fasilitas pengacak soal dan pengacak kunci jawaban ternyata sama-sama mengalami peningkatan 1 poin dari rata-rata sebelumnya 2,75 (pengacak soal) dan 2,9 (pengacak pilihan jawaban). Adapun penguasaan guru dalam menggunakan fasilitas pemberian nilai kuis meningkat sebesar 0,9 dari rata-rata sebelumnya 3,25. 
Terakhir pada kemampuan pembuatan kunci jawaban juga mengalami peningkatan dari rata-rata sebelumnya 3,35 meningkat menjadi 4,15.

Paparan di atas menunjukkan bahwa tujuan pelatihan yang diharapkan penulis telah tercapai. Kemampuan profesionalisme guru dalam mengggunakan Platform Google Form telah mengalami peningkatan yakni rata-rata kemampuan guru sebelum pelatihan sebesar 2,99 meningkat menjadi 3,99 setelah mengikuti pelatihan. Sedangkan berdasarkan pengamatan penulis selama kegiatan pelatihan, antusiasme peserta sangat baik. Peserta memperhatikan materi yang disampaikan oleh narasumber serta mengikuti simulasi penggunaan Platform Google Form dengan semangat, baik ketika berperan sebagai peserta didik dalam menjawab soal kuis maupun ketika sebagai guru dalam membuat soal di Google Form.

Dalam rangka mengasah keterampilan guru menggunakan Platform Google Form maka setelah pelatihan secara virtual, dilanjutkan dengan pendampingan menggunakan mode asinkron melalui Platform Google Classroom. Materi pelatihan juga diunggah di Google Classroom sehingga peserta bisa mempelajari kembali materi yang disampaikan secara virtual. Selain memberi kesempatan untuk diskusi lebih lanjut tentang materi pelatihan, pada ruang virtual asinkron juga peserta diberi tugas mengembangkan instrumen evaluasi berbasis online mata pelajaran matematika dengan bentuk kuis atau tes pilihan ganda sekurang-kurangnya 10 butir soal menggunakan Platform Google Form. Soal yang dikembangkan guru sangat dianjurkan yaitu soal yang akan diberikan terhadap peserta didik di sekolahnya. Peserta diberi waktu selama satu minggu mengerjakan, kemudian mengunggah file soal atau link-nya dalam Google Classroom.

Dari 38 peserta yang hadir pelatihan secara virtual ternyata hanya $47,36 \%$ saja yang mengumpulkan tugas sesuai petunjuk di Google Classroom. Kurangnya antusias peserta dalam mengerjakan tugas pengembangan instrumen evaluasi kemungkinan disebabkan banyak faktor. Salah satu kemungkinannya adalah waktu pelatihan yang berdekatan dengan masa Penilaian Akhir Semester (PAS) di sekolah sehingga konsentrasi peserta terbagi ke PAS. Sedangkan, dari hasil pekerjaan peserta yang mengumpulkan tugas pengembangan evaluasi berbasis online menunjukkan bahwa peserta telah menggunakan berbagai fitur Google Form sebagaimana disampaikan pada pelatihan secara virtual.

Selain dari pengamatan pemateri pada saat pelatihan via Zoom Meeting, antuasiasme peserta juga dilihat dari hasil kuesioner yang dibagikan di akhir rangkaian kegiatan pengabdian menggunakan Google Form yang dibagikan pada kelas virtual di Google Classroom. Hampir semua peserta yang mengisi kuesioner menyatakan bahwa materi pelatihan yang diberikan menarik, menambah pengetahuan baru, dan bermanfaat dalam pembelajaran daring. Adapun tanggapan lain dari peserta terhadap keseluruhan pelatihan adalah sebagai berikut:

a Pelatihan pengembangan evaluasi sangat berguna bagi kegiatan pembelajaran selama masa pandemi karena berbasis online dan nilai langsung bisa direkam. Hal ini memudahkan guru dalam mengukur KI 3

b Pelatihan ini sangat menarik, menyenangkan, dan banyak sekali hal baru yang saya dapatkan dari pelatihan tersebut. Acaranya benar-benar sangat menarik. Pelatihan ini membuat 
saya mendapatkan ilmu-ilmu baru yang belum pernah saya dapatkan.

c Saya merasa terbantu dengan adanya pelatihan ini, pengetahuan saya bertambah, dan saya senang mengikutinya.

d Kegiatannya menarik dan bisa memperluas wawasan tentang berbagai aplikasi yang dapat mendukung pembelajaran daring dimasa pandemi Covid-19.

e Saya jadi bertambah keilmuan dalam mengoperasikan kuis online yang sangat efektif digunakan di masa pembelajaran jarak jauh

f Lebih praktis dan menarik.

Sedangkan harapan peserta kedepannya supaya ada pelatihanpelatihan serupa dengan durasi lebih lama agar peserta benar-benar menguasai materi yang disampaikan.

Berdasarkan respon peserta maka dari hasil pelatihan ini dapat digunakan untuk meningkatkan kualitas pembelajaran matematika khususnya di kelas V SD/MI Muhammadiyah di Bantul menjadi lebih baik. Apalagi di masa pembelajaran daring seperti sekarang ini, tentu keterampilan mengembangkan instrumen evaluasi berbasis online sangat diperlukan guru untuk memperlancar tugasnya mendidik peserta didik. Kalaupun pembelajaran nanti sudah memasuki era kenormalan baru dimana pembelajaran sudah kembali tatap muka langsung, keterampilan menggunakan Platform Google Form masih relevan di dunia Pendidikan karena tidak menutup kemungkinan ke depannya akan ada beberapa pekerjaan yang masih dikerjakan secara online memanfaatkan teknologi digital yang berkembang dengan alasan keefektifan dan keefisienannya. Apalagi kita dihadapkan pada era industri 4.0, integrasi teknologi digital dalam pembelajaran khususnya matematika menjadi tak terelakkan lagi karena pentingnya teknologi digital dalam pembelajaran matematika (Putrawangsa \& Hasanah, 2018). Selain itu juga, pada era industri 4.0 perkembangan teknologi cyber menjadi sangat pesat. Para pakar Teori Pendidikan menggunakan istilah Pendidikan 4.0 untuk menggambarkan berbagai cara yang mengintegrasikan teknologi cyber dalam pembelajaran (Lase, 2019). Sehingga guru perlu dibekali dengan keterampilan yang berkenaan dengan teknologi digital dalam pembelajaran.

Secara keseluruhan rangkaian kegiatan pengabdian dalam dua mode, sinkron dan asinkron, tentu ada kelebihan dan kekurangannya. Kelebihan pelatihan secara virtual adalah efektif dan efisien waktu serta menghemat tempat dan tenaga baik bagi narasumber maupun peserta. Pelatihan secara virtual bisa diakses dimana saja dan bahkan bisa sambil mengerjakan pekerjaan lain, meskipun hal ini tentu akan menganggu konsentrasi terhadap materi yang diberikan. Namun, bagi beberapa orang yang terbiasa multitasking tentu hal ini masih bisa diikuti. Adapun kekurangan pelatihan secara virtual adalah jaringan internet yang terkadang kurang stabil, gangguan pada piranti yang digunakan seperti laptop atau gadget, serta kejadian tak terduga seperti mati listrik. Pada pelatihan virtual juga masih dijumpai peserta tidak mengaktifkan video dan audio, sehingga tidak diketahui apakah peserta masih memperhatikan materi yang disampaikan pemateri atau tidak. Hal ini sepertinya sudah banyak terjadi pada forum webinar online. Namun demikian, ini bukanlah masalah besar karena terbukti pada pelatihan pengabdian ini peserta bisa mengikuti pelatihan dengan baik dan mengerjakan tugas yang diberikan dengan baik. 


\section{Kesimpulan dan Saran}

Hasil kegiatan pelatihan yang dilakukan dapat disimpulkan bahwa terdapat peningkatan profesionalisme guru dalam melakukan evaluasi pembelajaran secara online menggunakan Platform Google Form. Peserta telah memahami fasilitasfasilitas apa saja yang bisa dioptimalkan ketika mengembangkan instrumen evaluasi online menggunakan Platform Google Form. Selain itu, peserta telah mendapatkan pengalaman dengan cara praktik langsung mengembangkan soal kuis menggunakan Google Form dan praktik menjadi peserta didik dalam mengisi kuis pada Google Form.

Hasil kegiatan pengabdian ini bisa digunakan untuk memperbaiki kualitas pembelajaran daring di SD/MI Muhammadiyah di Bantul khususnya pada pembelajaran matematika di kelas V. Adapun untuk kegiatan serupa selanjutnya, disarankan supaya dipilih aplikasi yang benar-benar diperlukan oleh peserta dengan durasi pelatihan yang cukup sehingga materi bisa disampaikan secara mendalam agar peserta bisa menguasai materi dengan sempurna.

\section{UcapanTerimakasih}

Penulis mengucapkan terima kasih kepada LPPM UAD yang telah mendanai Kegiatan Pengabdian Kepada Masyarakat (PKM) untuk tahun anggaran 2020. Penulis juga mengucapkan terimakasih kepada Majelis Dikdasmen PDM Bantul yang telah memberikan ijin dan fasilitas untuk terselenggaranya PKM kami, kepala sekolah SD/MI Muhammadiyah se-Bantul yang telah memberikan ijin bagi bapak ibu guru peserta, serta seluruh peserta bapak ibu guru kelas $\mathrm{V}$ SD/MI Muhammadiyah se-Bantul yang telah berpartisipasi dalam kegiatan PKM ini.

\section{DAFTAR PUSTAKA}

Astuti, D., Kartono, \& Wardono. (2018). Analisis Kemampuan Literasi Matematika Model Pembelajaran JUCAMA berpendekatan PMRI dengan Google Form sebagai Self Assessment. PRISMA, Prosiding Seminar Nasional Matematika, 1, 69-76.

Bahri, S., Simbolon, M., Sari, D. K., \& Rettob, A. L. (2020). Pelatihan Penggunaan Fasilitas Google dalam Kegiatan Pembelajaran untuk Meningkatkan Kompetensi Pedagogik. ETHOS: Jurnal Penelitian Dan Pengabdian Kepada Masyarakat, 8(2), 205-211. https://doi.org/10.29313/ethos.v8i2. 5436

Basilaia, G., \& Kvavadze, D. (2020). Transition to Online Education in Schools during a SARS-CoV-2 Coronavirus (COVID-19) Pandemic in Georgia. Pedagogical Research, $5(4)$.

https://doi.org/10.29333/pr/7937

Batubara, H. H. (2016). Penggunaan Google Form sebagai Alat Penilaian Kinerja Dosen di Prodi PGMI UNISKA Muhammad Arsyad Al Banjari. Al-Bidayah: Jurnal Pendidikan Dasar Islam, 8(1), 4050.

Djusar, S., Taslim, \& Toresa, D. (2020). Pengaruh kemudahan, kebutuhan, kemampuan, minat terhadap persepsi guru dalam menggunakan aplikasi google. ETHOS: Jurnal Penelitian Dan Pengabdian Kepada Masyarakat, 8(2), 242-247.

Favale, T., Soro, F., Trevisan, M., Drago, I., \& Mellia, M. (2020). Campus traffic and e-Learning during COVID-19 pandemic. Computer Networks, 176, 107290. https://doi.org/10.1016/j.comnet.202 0.107290 
Kemendikbud. (2020). Surat Edaran Nomor 4 Tahun 2020 tentang Pelaksanaan Kebijakan Pendidikan dalam Masa Darurat Penyebaran Coronavirus Disease (COVID-19). Kemendikbud.

Krisnawati, E. (2018). Pemanfaatan Google Form Sebagai Kuis Online Mata Kuliah Trigonometri. JP2M (Jurnal Pendidikan Dan Pembelajaran Matematika), 4(1), 61-67.

https://doi.org/10.29100/jp2m.v4i1. 1779

Lase, D. (2019). Pendidikan di Era revolusi Industri 4.0. Journal Sunderman, $\quad 1(1), \quad 28-43$. https://doi.org/https://doi.org/10.365 88/sundermann.v1i1.18

Putrawangsa, S., \& Hasanah, U. (2018). Integrasi Teknologi Digital Dalam Pembelajaran Di Era Industri 4.0 Kajian dari Perspektif Pembelajaran Matematika. Jurnal Tatsqif: Jurnal Pemikiran Dan Penelitian Pendidikan, 16(1), 42-54.

Radwan, A., \& Radwan, E. (2020). Social and Economic Impact of School Closure during the Outbreak of the COVID-19 Pandemic: A Quick Online Survey in the Gaza Strip. Pedagogical Research, 5(4), em0068.

https://doi.org/10.29333/pr/8254

Ritonga, M., Lahmi, A., Rimelfi, R., Bahri, F., \& Bagindo, I. T. (2020). Sosialisasi Pembuatan Soal Melalui Google Form Dalam Meningkatkan Kompetensi Guru Pai. BERNAS: Jurnal Pengabdian Kepada Masyarakat, 1(4), 347-354. https://doi.org/10.31949/jb.v1i4.456

Sintema, E. J. (2020). Effect of COVID-19 on the performance of grade 12 students: Implications for STEM education. Eurasia Journal of Mathematics, Science and Technology Education, 16(7), 1-6.
https://doi.org/10.29333/EJMSTE/7 893

Siregar \& Restati. (2017). Persepsi Siswa Pada Pelajaran Matematika: Studi Pendahuluan Pada Siswa yang Menyenangi Game. Prosiding Temu Ilmiah $X$ Ikatan Psikologi Perkembangan Indonesia, 224-232. https://www.google.co.id/search?q= Persepsi + siswa + pada + pelajaran + ma tematika\%253A+studi+pendahuluan + pada+siswa+yang + menyenangi + ga me+Nani+Restati+Siregar1+1Maha siswa+Program+Doktor+Psikologi+ Universitas + Gadjah + Mada\&oq $=$ Per sepsi + siswa + pada + pelajaran + mate matika

Viner, R. M., Russell, S. J., Croker, H., Packer, J., Ward, J., Stansfield, C., Mytton, O., Bonell, C., \& Booy, R. (2020). School closure and management practices during coronavirus outbreaks including COVID-19: a rapid systematic review. In The Lancet Child and Adolescent Health (Vol. 4, Issue 5, pp. 397-404). Elsevier B.V. https://doi.org/10.1016/S23524642(20)30095-X

Yusron, R. M., Wijayanti, R., \& Novitasari, A. T. (2020). Pelatihan Pembuatan Google Form bagi Guru SD Sebagai Media Evaluasi Pembelajaran Jarak Jauh (PJJ) Masa Pandemi. Jurnal Publikasi Pendidikan, 10(3), 182-188. https://doi.org/10.26858/publikan.v1 $0 \mathrm{i} 3.15055$

Zayapragassarazan, Z. (2020). COVID19: Strategies for Online Engagement of Remote Learners. F1000Research, 246, 1-11. https://doi.org/10.7490/F1000RESE ARCH.1117835.1

Zhang, W., Wang, Y., Yang, L., \& Wang, C. (2020). Suspending Classes Without Stopping Learning: China's Education Emergency Management Policy in the COVID- 
19 Outbreak. Journal of Risk and Financial Management, 13(3), 55. https://doi.org/10.3390/jrfm1303005 5 